\title{
PENGARUH LAMA PAPARAN PENGIKAT CINCIN ELASTOMER ORTODONTI TERHADAP KUALITAS DNA
}

\author{
*Januar alif **Ahmad Yudianto \\ *Program Magister Ilmu Forensik Universitas Airlangga

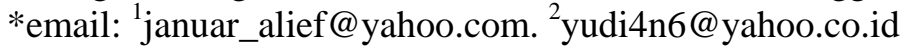

\begin{abstract}
Abstrak
Cincin elastomer merupakan salah satu bagian dari piranti ortodonti cekat yang berfungsi mengikatkan kawat busur ke breket. Cincin tersebut dapat kontak langsung dengan mukosa mulut sehingga adanya sel epitel mukosa terlepas dan menempel pada cincin elastomer. Salah satu faktor yang mempengaruhi kualitas DNA adalah lama paparan disamping faktor lain seperti suhu, kelembapan, paparan zat kimia, dan enzim yang merusak DNA (DNAase). kualitas DNA ditentukan dari kadar dan kemurniannya. Visualisasi hasil PCR adalah lokus STR : D13S317 dan D18S51, karena memiliki daya diskriminasi besar pada populasi Indonesia. Penelitian ini bertujuan menjelaskan cincin elastomer ortodonti dapat digunakan sebagai alat identifikasi DNA untuk kepentingan forensik. Penelitian ini merupakan penelitian observasional eksplanasi dengan rancangan longitudinal prospektif. Pengumpulan data dilakukan dengan cara membandingkan dua periode paparan, 7 hari dan 14 hari terhadap kualitas DNA yang diamati secara berurutan (time series). Terdapat perbedaan kadar DNA antara lama paparan 7 hari dan 14 hari dimana nilai $\mathrm{P}$ pada uji statistik adalah $\mathrm{P}=0,012(\mathrm{P}<0,05)$. terdapat perbedaan kemurnian DNA antara lama paparan 7 hari dan 14 hari dimana nilai $\mathrm{P}$ uji statistik didapatkan $\mathrm{P}=0,016(\mathrm{P}<0,05)$. Data yang diperoleh disimpulkan bahwa cinicn elastomer dapat digunakan sebagai alat identifikasi DNA untuk kepentingan Forensik.
\end{abstract}

kata kunci : Cincin Elastomer, Kadar, Kemurnian, Lama Paparan

\section{THE EFFECT OF LONG EXPOSURE BINDER RINGS OF QUALITY DNA FROM ELASTOMERS ORTHODONTIC}

\begin{abstract}
Elastomeric is one part of a fixed orthodontic device that serves to tie the wire arc into brackets. The ring can be direct contact with the oral mucosa so that the presence of mucosal epithelial cells detached and attached to the elastomer chain. One of the factors that affect the quality of the DNA is a long exposure in addition to other factors such as temperature, humidity, exposure to chemicals, and enzymes that damage DNA (DNAase). DNA quality is determined from the concentration and purity. Visualization of PCR results are STR loci: D13S317 and D18S51, because it has a large discrimination in Indonesia's population. This study aimed to describe the orthodontic elastomeric chain can be used as a tool for the benefit of forensic DNA identification. This study was an observational study design with prospective longitudinal explanation. The data collection is done by comparing the two periods of exposure, 7 days and 14 days on the quality of DNA were observed in sequence (time series). There are differences in the levels of DNA between long exposure to 7 days and 14 days where the statistical test $\mathrm{P}$ value is $\mathrm{P}=0.012(\mathrm{P}$ $<0.05)$. Purity DNA differences between long exposure to 7 days and 14 days when the $\mathrm{P}$ value obtained statistical test $\mathrm{P}=0.016(\mathrm{P}<0.05)$ The data obtained can be concluded that elastomeric chain can be used as a tool for the benefit of Forensic DNA identification.
\end{abstract}

Keyword: Concentration, Elastomeric Chain, Exposure, Purity 


\section{PENDAHULUAN}

Metode identifikasi meliputi sidik jari, gigi geligi, analisa DNA, properti dan medis. Armed Forces DNA Identification Laboratory (AFDIL), menyatakan metode pemeriksaan gigi geligi mempunyai nilai akurasi cukup tinggi sekitar 70-79\% ketika digunakan dalam analisis DNA untuk proses identifikasi. Beberapa faktor yang mempengaruhi pemeriksaan gigi geligi dalam identifikasi yakni penggunaan kawat gigi atau piranti ortodonti.

Tujuan utama perawatan ortodonti adalah mendapatkan penampilan susunan gigi dan wajah yang menyenangkan secara estetika dengan fungsi yang baik dan gigi geligi dalam posisi yang stabil. Piranti ortodonti cekat mempunyai 3 komponen utama yaitu : Lekatan (attachment) yang berupa breket (bracket), cincin (band) kawat busur (archwire) dan penunjang (auxiliaries) misalnya rantai elastomerik dan cincin elastomerik (Raharjo, 2009). Cincin elastomer merupakan salah satu bagian dari piranti ortodonti cekat yang berfungsi mengikatkan kawat busur ke breket. Menurut Marks dkk, (1989) Sifat cincin elastomer adalah mengabsorbsi cairan selama dalam mulut, sehingga kehilangan daya renggang, tidak dapat memegang busur masuk pada slot breket serat kawat ligature Stainless Steel, mengalami perubahan warna dan menimbulkan bau bila tidak diganti pada periode waktu yang dianjurkan. Cincin tersebut dapat kontak langsung dengan mukosa mulut sehingga adanya sel epitel mukosa terlepas dan menempel pada cincin elastomer. Penderita yang menjalani perawatan ortodonti, tidak menuntut kemungkinan untuk terlibat dalam tindak kriminal baik menjadi korban maupun pelaku atau menjadi korban kecelakaan yang memerlukan identifikasi (Pertiwi dan Evi, 2011).

Identifikasi melalui analisi DNA mempunyai 2 tujuan : tujuan paternitas yaitu mengetahui hubungan biologis antar individu dalam sebuah keluarga dengan cara membandingkan pola DNA individu individu tersebut, tujuan hukum meliputi masalah forensik seperti identifikasi korban yang tidak bisa dikenali secara fisik sehingga diperlukan pencocokan DNA korban dengan keluarga korban, ataupun untuk pembuktian kejahatan seperti kasus perkosaan dan pembunuhan. Analisa DNA merupakan teknik analisis untuk mengidentifikasi suatu individu berdasarkan fragment DNA-nya. Keuntungan analisis DNA adalah mengetahui hubungan kekerabatan, karakteristik dan penanda suatu spesies baik hewan maupun tumbuhan (Val McDermid, 2014). Sidik DNA individu berbeda-beda sehingga dapat digunakan sebagai bukti forensik pada kasus kejahatan. Sejauh ini identifikasi melalui analisis DNA pada cincin elastomer ortodonti belum banyak diketahui.

Teknik pemeriksaan DNA meliputi DNA inti dan DNA mitokondria. Pemeriksaan DNA inti yaitu Restriction Fragment Length Polymorphism (RFLP), Analisis Polymerase chain reaction (PCR), Teknik analisis STR (Short Tandem Repeats), Teknik Analisis AmpFLP ( Amplified Fragment Length Polymorfisem ).

Deoxyribose Nucleic Acid (DNA) dari kromosom sel tubuh atau autosom yang mengandung area Short Tandem Repeat (STR), yaitu suatu area yang tidak memberikan kode untuk melakukan sesuatu. STR inilah yang bersifat unik karena berbeda pada setiap orang, perbedaannya terdapat pada urutan basa yang dihasilkan dari urutan pengulangannya. Short Tandem Repeat merupakan teknik DNA profiling yang sering digunakan. Federal Bureau of Investigation (FBI) merekomendasikan 13 locus combined DNA Identification system (CODIS) yaitu TH01, TPOX, CSF1PO, vWA, FGA, D3S1358, D5S818, D7S820, D13S317, D16S539, D8S1179, D18S51, D21S11, dan Amelogen. Pola STR diwariskan dari kedua orangtuanya. Seseorang dapat dikatakan dapat memiliki hubungan darah jika memiliki urutan dan pengulangan setidaknya pada 13 STR yang sama dengan keluarga kandungnya. Kemungkinan dua individu mempunyai 13 locus yang sama pada profil DNA-nya adalah sangat jarang. Terdapat beberapa faktor yang mempengaruhi kualitas DNA yakni, Suhu, Waktu paparan, Kelembaban (dapat mempengaruhi pertumbuhan mikroorganisme), paparan zat kimia, sinar UV (lampu, Sinar matahari), dan enzim - enzim yang merusak DNA (DNAse) (Yudianto, 2015). Pengukuran kadar dan kemurnian dengan menggunakan UV spektrofotometer, kadar ditentukan dengan formula $=\mathrm{OD}_{260} \times \mathrm{FP}$ 
x 50 (ds DNA) $\mu g / m l$. Sedangkan kemurnian DNA diukur dengan membandingkan nilai $\mathrm{OD}_{260}$ dan $\mathrm{OD}_{280}$. Bila nilai rasio antara 1,8 - 2 merupakan DNA murni. Pada recana penelitian ini visualisasi hasil PCR adalah lokus STR : D13S317 dan D18S51 karena memiliki daya diskriminasi besar pada populasi Indonesia.

Pengambilan sampel DNA pada cincin elastomer ortodonti dimulai 7 hari setelah pemasangan didalam rongga mulut kemudian 14 hari. Menurut Taloumis dkk., (1997) kekuatan cicin elastomer pada percobaan invitro mencapai $50 \%$ - $60 \%$ selama 24 jam pertama, berlanjut rata-rata 7 sampai 10 hari sudah menandakan adanya deformasi yang permanen.

\section{ILMU FORENSIK DAN KRIMINALISTIK \\ Ilmu forensik (biasa disingkat} forensik) adalah sebuah penerapan dari berbagai ilmu pengetahuan untuk menjawab pertanyaan-pertanyaan yang penting untuk sebuah sistem hukum yang mana hal ini mungkin terkait dengan tindak pidana. Namun disamping keterkaitannya dengan sistem hukum, forensik umumnya lebih meliputi sesuatu atau metode-metode yang bersifat ilmiah (bersifat ilmu) dan juga aturan-aturan yang dibentuk dari fakta-fakta berbagai kejadian, untuk melakukan pengenalan terhadap bukti-bukti fisik ( contohnya mayat atau bangkai dan sebagainya ). Untuk pengertian yang lebih mudahnya, Ilmu forensik adalah ilmu untuk melakukan pemeriksaan dan pengumpulan bukti-bukti fisik yang ditemukan di tempat kejadian perkara dan kemudian dihadirkan di dalam sidang pengadilan. Forensik menurut Genge. (2003), berasal dari bahasa Yunani 'Forensis' yang berarti debat atau perdebatan adalah bidang ilmu pengetahuan yang digunakan untuk membantu proses penegakan keadilan melalui proses penerapan ilmu ( sains ). Dalam kelompok ilmu-ilmu forensik ini dikenal antara lain ilmu fisika forensik, ilmu kimia forensik, ilmu psikologi forensik, ilmu kedokteran forensik, ilmu toksikologi forensik, komputer forensik, ilmu balistik forensik, ilmu metalurgi forensik dan sebagainya. Dari pengertian-pengertian forensik maupun kriminalistik terdapat beberapa unsur yang sama yaitu :

1. Ada satu metode, peralatan, proses dan pekerjaan;

2. Dengan mendayagunakan ilmu pengetahuan dengan teknologi terapan;

3. Dilakukannya terhadap suatu benda yang berhubungan dengan suatu tindakan pidana;

4. Bertujuan untuk membuat jelas suatu perkara sehingga hasilnya dapat digunakan sebagai bukti di pengadilan;

Dari berbagai pendapat diatas dan dari berbagai pendapat yang dikumpulkan maka pendefinisian terhadap ilmu forensik dan kriminalistik adalah:

Ilmu forensik adalah penerapan ilmu pengetahuan dengan tujuan penetapan hukum dan pelaksanaan hukum dalam sistem peradilan hukum pidana maupun hukum perdata.

Kriminalistik adalah penerapan dari berbagai ilmu pengetahuan dengan metode dan analisa ilmiah untuk memeriksa bukti fisik dengan tujuan untuk membuktikan ada tidaknya suatu tindak pidana.

\subsection{Kegunaan Ilmu Forensik}

Untuk dapat membuat terang suatu perkara dengan cara memeriksa dan menganalisa barang bukti mati, sehingga dengan ilmu forensik haruslah didapat berbagai informasi, menurut Genge ( 2003 ) yaitu :

1) Information on corpus delicti, dari pemeriksaan baik TKP maupun barang bukti dapat menjelaskan dan membuktikan bahwa telah terjadi suatu tindak pidana;

2) Information on modus operandi, beberapa pelaku kejahatan mempunyai cara - cara tersendiri dalam melakukan kejahatan dengan pemeriksaan barang bukti kaitannya dengan modus operandi sehingga dapat diharapkan siapa pelakunya;

3) Linking a suspect with a victim, pemeriksaan terhadap barang bukti di TKP ataupun korban dapat mengakibatkan keterlibatan tersangka dengan korban, karena dalam suatu tindak pidana pasti ada material dari tersangka yang tertinggal pada korban; 
4) Linking a person to a crime scene, setelah terjadi tindak pidana banyak kemungkinan terjadi terhadap TKP maupun korban yang dilakukan oleh orang lain selain tersangka mengambil keuntungan;

5) Disproving or supporting a Witness 's Testimony, pemeriksaan terhadap barang bukti dapat memberikan petunjuk apakah keterangan yang diberikan oleh tersangka ataupun saksi berbohong atau tidak;

6) Identification of a suspect, barang bukti terbaik yang dapat digunakan untuk mengindentifikasi seorang tersangka adalah sidik jari, karena sidik jari mempunyai sifat sangat karakteristik dan sangat individu bagi setiap orang;

7) Providing Investigative leads, pemeriksaan dari barang bukti dapat memberikan arah yang jelas dalam penyidikan.

Ada beberapa subdivisi dari Ilmu Forensik, antara lain :

\section{- Criminalistics}

Adalah subdivisi dari ilmu forensik yang menganalisa dan menjawab pertanyaanpertanyaan yang berkaitan dengan buktibukti biologis, bukti jejak, bukti cetakan (seperti sidik jari, jejak sepatu, dan jejak ban mobil), controlled substances (zat-zat kimia yang dilarang oleh pemerintah karena bisa menimbulkan potensi penyalahgunaan atau ketagihan), ilmu balistik (pemeriksaan senjata api) dan bukti-bukti lainnya yang ditemukan pada TKP. Biasanya, bukti-bukti tersebut diproses didalam sebuah laboratorium (crime lab).

- Forensic Anthropology

Adalah subdivisi dari ilmu forensik yang menerapkan ilmu antropologi fisik (yang mana dalam arti khusus adalah bagian dari ilmu antropologi yang mencoba menelusuri pengertian tentang sejarah terjadinya beraneka ragam manusia dipandang dari sudut ciri-ciri tubuhnya) dan juga menerapkan ilmu osteologi (yang merupakan ilmu anatomi dalam bidang kedokteran yang mempelajari tentang struktur dan bentuk tulang khususnya anatomi tulang manusia) dalam menganalisa dan melakukan pengenalan terhadap bukti-bukti yang ada (contoh penerapan dari ilmu forensik ini adalah misalnya melakukan pengenalan terhadap tubuh mayat yang sudah membusuk, terbakar, dimutilasi atau yang sudah tidak dapat dikenali).

- Digital Forensic yang juga dikenal dengan nama Computer Forensic

Adalah salah satu subdivisi dari ilmu forensik yang melakukan pemeriksaan dan menganalisa bukti legal yang ditemui pada komputer dan media penyimpanan digital, misalnya seperti flash disk, hard disk, CDROM, pesan email, gambar, atau bahkan sederetan paket atau informasi yang berpindah dalam suatu jaringan komputer.

- Forensic Enthomology

Adalah aplikasi ilmu serangga untuk kepentingan hal-hal kriminal terutama yang berkaitan dengan kasus kematian. Entomologi forensik mengevaluasi aktifitas serangga dengan berbagai teknik untuk membantu memperkirakan saat kematian dan menentukan apakah jaringan tubuh atau mayat telah dipindah dari suatu lokasi ke lokasi lain. Entomologi tidak hanya bergelut dengan biologi dan histologi artropoda, namun saat ini entomologi dalam metode-metodenya juga menggeluti ilmu lain seperti kimia dan genetika. Dengan penggunaan pemeriksaan dan pengidentifikasi DNA pada tubuh serangga dalam entomologi forensik, maka kemungkinan deteksi akan semakin besar seperti akan memungkinkan untuk mengidentifikasi jaringan tubuh atau mayat seseorang melalui serangga yang ditemukan pada tempat kejadian perkara.

- Forensic Archaeology

Adalah ilmu forensik yang merupakan aplikasi dari prinsip-prinsip arkeologi, teknik-teknik dan juga metodologimetodologi yang legal / sah. Arkeolog biasanya dipekerjakan oleh polisi atau lembaga-lembaga hukum yang ada untuk membantu menemukan, menggali buktibukti yang sudah terkubur pada tempat kejadian perkara.

- Forensic Geology

Adalah ilmu yang mempelajari bumi dan menghubungkannya dengan ilmu kriminologi. Melalui analisis tanah, batuan, forensik geologist dapat menentukan dimana kejahatan terjadi. Contoh kasus : beton dari sebuah tempat yang diduga 
diledakkan kemudian mengalami kebakaran akan memiliki ciri fisik yang berbeda dengan beton yang hanya terbakar saja tanpa adanya ledakan. Ledakan sebuah bom, misalnya mungkin akan memiliki perbedaan dengan ledakan dinamit. Secara "naluri" seorang forensik geologist akan mengetahui dengan perbedaan bahwa batuan yang ditelitinya mengalami sebuah proses diawali dengan hentakan dan pemanasan. Atau hanya sekedar pemanasan.

- Forensic Meteorology

Adalah ilmu untuk merekonstruksi kembali kejadian cuaca yang terjadi pada suatu lokasi tertentu. Hal ini dilakukan dengan mengambil arsip catatan informasi cuaca yang meliputi pengamatan suatu permukaan bumi, radar, satelit, informasi sungai, dan lain sebagainya pada lokasi tersebut. Forensik meteorologi paling sering digunakan untuk kasus-kasus pada perusahaan asuransi (mengclaim gedung yang rusak karena cuaca misalnya) atau investigasi pembunuhan (contohnya apakah seseorang terbunuh oleh kilat ataukah dibunuh).

- Forensic Odontology

Adalah ilmu forensik untuk menentukan identitas individu melalui gigi yang telah dikenal sejak era sebelum masehi. Kehandalan teknik identifikasi ini bukan saja disebabkan karena ketepatannya yang tinggi sehingga nyaris menyamai ketepatan teknik sidik jari, akan tetapi karena kenyataan bahwa gigi dan tulang adalah material biologis yang paling tahan terhadap perubahan lingkungan dan terlindung. Gigi merupakan sarana identifikasi yang dapat dipercaya apabila rekaman data dibuat secara baik dan benar. Beberapa alasan dapat dikemukakan mengapa gigi dapat dipakai sebagai sarana identifikasi adalah sebagai berikut : 1) Gigi adalah merupakan bagian terkeras dari tubuh manusia yang komposisi bahan organik dan airnya sedikit sekali dan sebagian besar terdiri atas bahan anorganik sehingga tidak mudah rusak, terletak dalam rongga mulut yang terlindungi ; 2) Manusia memiliki 32 gigi dengan bentuk yang jelas dan masing-masing mempunyai lima permukaan.

- Forensic Pathology
Adalah cabang dari ilmu forensik yang berkaitan dengan mencari penyebab kematian berdasarkan pemeriksaan pada mayat (otopsi). Ahli patologi secara khusus memusatkan perhatian pada posisi jenazah korban, bekas-bekas luka yang tampak, dan setiap bukti material yang terdapat di sekitar korban, atau segala sesuatu yang mungkin bisa memberikan petunjuk awal mengenai waktu dan sebab-sebab kematian.

- Forensic Psychiatry dan Psychology Adalah ilmu forensik yang menyangkut keadaan mental tersangka atau para pihak dalam perkara perdata. Ilmu forensik sangat dibutuhkan jika di dalam suatu kasus kita menemukan orang yang purapura sakit, anti sosial, pemerkosa, pembunuh, dan masalah yang menyangkut seksual lainnya seperti homoseksual, waria, operasi ganti kelamin, pedofilia, dan maniak.

- Forensic Toxicology

Adalah penggunaan ilmu toksikologi dan ilmu-ilmu lainnya seperti analisis kimia, ilmu farmasi dan kimia klinis untuk membantu penyelidikan terhadap kasus kematian, keracunan, dan penggunaan obat-obat terlarang. Fokus utama pada forensik toksikologi bukan pada hasil dari investigasi toksikologi itu sendiri, melainkan teknologi atau teknik-teknik yang digunakan untuk mendapatkan dan memperkirakan hasil tersebut.

\subsection{CINCIN ELASTOMER}

Produk elastomer yang dipakai dalam praktek ortodonti adalah sebagai ligatur dan sebagai modul kontinyu atau chain biasa dipakai untuk mengikat dan meretaksi gigi. Diperkenalkan lebih dari tiga dekade dan sangat disukai, rantainya adalah polyurethanememiliki thermosetting polymer a- $(\mathrm{NH})-(\mathrm{C}=\mathrm{O})-\mathrm{O}-\quad$ (Taloumis dkk, 1997). Pembuatan polyurethane elastomer terdiri dari beberapa tahap :

- Tahap dasar (Polymer molekul tingkat rendah) Disebut juga tahap pembentukan polyester atau polyether.

- Tahap dasar bereaksi dengan aromatic di isocyanate menghasilkan Prepolymer, elastomer keluar melalui grup isocyanate dengan reaksi alcohol atau glycols (Baty dkk, 1994). 
Elastomer memiliki elastisitas mirip karet, mempunyai temperatur transisi gelas berkisar -50 sampai -80 derajad Celsius. Temperatur transisi gelas adalah temperature di mana sifat dari polymer menjadi elastis. Suhu dibawah temperatur transisi gelas gerak molekul berupa getaran sehingga ada kelenturan, suhu diatas Temperatur transisi gelas gerak molekul menjadi terarah sehingga materi elastomer jadi elastis. Sedangkan semakin tinggi diatas Temperatur transisi gelas polymernya menjadi kaku hal ini disebabkan karena nilai modulus elastisitasnya tinggi.

Ligatur Elastomer memiliki ukuran 0,008 - 0,0014 inci, lebih disukai karena memiliki warna yang bervariasi, mudah aplikasinya dan pengurangan tekanan pada busur ke slot breket sehingga sangat cocok dipakai pada tahap leveling dan unreveling. Kelemahan dari cincin elastomer yaitu saat dipakai untuk koreksi rotasi dan torque tidak optimal karena terjadi deformasi yang permanen. Menurut (Taloumis dkk, 1997), bahwa kekuatan cincin elastomer pada percobaan in vito mencapai $50-60 \%$ selama 24 jam pertama berlanjut rata-rata $7-10$ hari sudah menandakan adanya deformasi yang permanen. Rantai elastomer memiliki kelemahan di dalam mulut, hal ini terjadi karena air menjadi plasticzer melemahkan kekuatan intramolekul dalam polyurethane dan hal ini menyebabkan degradasi kimia. Variasi $\mathrm{pH}$ dan temperatur dalam mulut karena akumulasi plak dan pembentukan koloni bakteri mempengaruhi susunan, sifat permukaan konformasi polyurethane (Fadel dkk, 1992).

\subsubsection{Beberapa keuntungan pemakaian cincin elastomer di bidang ortodonti : \\ Sesudah 7 hari dalam mulut}

kekuatannya masih mendekati daya renggang semula. Lebih popular karena lebih cepat untuk dilepas dan dipasang, sehingga mengurangi waktu periksa pasien (Marks dkk, 1989). Relatif murah , bersih mudah digunakan dan bahkan tidak menuntut kerja sama pasien (Baty dkk, 1994).

Sebagai alternatif pengganti fungsi kawat ligatur untuk member tekanan sedang berkelanjutan sehingga kedudukan busur pada slot breket menjadi tahan lama dan konsisten (Taloumis dkk, 1997).

\subsubsection{Beberapa sifat yang kurang baik pada cincin elastomer ortodonti}

Mengabsorbsi cairan selama dalam mulut, sehingga kehilangan daya renggang, tidak dapat memegang busur masuk pada slot breket seerat kawat ligature Stainless Steel, mengalami perubahan warna dan menimbulkan bau bila tidak digantipada periode waktu yang dianjurkan (Marks dkk, 1989).

Bila direnggangkan dan terpapar pada lingkungan mulut akan menyerap air dan saliva, mengalami noda permanen dan ikatan internalnya putus. Ikatan internal yang putus menyebabkan deformasi permanen cepat terjadi penurunan daya akibat relaksasi, selain itu daya yang ditransmisikan ke gigi juga sulit diukur (Baty dkk, 1994).

Berpengaruh buruk pada gigi dan jaringan lunak karena akumulasi kuman pada permukaan gigi di dekat breket yang diikat dengan cincin elastomer. Juga busur tidak bisa masuk sepenuhnya pada slot breket selama torque atau rotasi dan terjadi ikatan (binding) pada mekanisme geser. Karena sifatnya yang cepat mengalamin penurunan daya dan terjadi deformasi permanen maka cincin elastomer cocok digunakan selama aligning dan leveling awal, dan tidak sesuai untuk menyelesaikan seluruh tahap perawatan ortodonti (Taloumis dkk, 1997).

\subsubsection{Sifat sifat lain dari cincin elastomer ortodonti}

Berubah warna dan terpengaruh warnanya akibat makanan dan minuman yang sering dikonsumsi dengan derajad perubahan sebagai berikut (Fadel dkk, 1992) :

- Elastomer warna transparan, putih dan warna mirip gigi mengalami perubahan warna yang paling kuat, cenderung berubah warna sama sekali;

- Elastomer warna kuning, biru dan pink juga kuat perubahannya warnanya;

- Elastomer violet dan hijau mengalami perubahan warna dengan derajad sedang ;

- Elastomer warna kelabu, merah oranye sedikit mengalami perubahan warna;

Dalam kondisinkritis semua elastomer ortodonti bersifat sitotoksik namun secara klinis efek tersebut tidak kelihatan, karena lateks alam termasuk kategori GRAS 
(Generally Regarded as Safe) atau bahan yang secara umum dianggap aman. Bahan elastomer terdiri dari lateks alami dengan bahan tambahan 3\% ( sulfur $0,87 \%$, Zinkoksida $0,6 \%$, dan akselerator vulkanisasi $0,5 \%)$. Pewarna pada elastomer ortodonti adalah pewarna makanan dan elastomer yang berwarna jernih maupun neon tidak memiliki pengaruh sitotoksik secara klinis karena adanya faktor saliva atau factor yang terkait dengan jaringan (Holmes dkk, 1993).

Elastomer sintetil sangat peka terhadap pengaruh system yang menghasilkan radikal bebas (terutama ozon dan ultraviolet) karena menyebabkan penurunan fleksibilitas dan daya renggangnya. Untuk mengatasi, produsen menambahkan anti oksidan dan antiozonat untuk menghambat pengaruh radikal bebas dan untuk memperpanjang waktu simpan elastomer. Deformasi, degradasi daya dan relaksasi elastomer terkait dengan factor lingkungan yaitu gerak gigi, perubahan suhu, variasi $\mathrm{pH}$, bilasan fluorida mulut, enzim saliva dan daya kunyah (Baty dkk, 1994).

\subsection{DNA dan Informasi Genetis}

Dahulu kala, para peneliti menyatakan bahwa materi genetik berada di dalam struktur yang disebut kromosom dalam inti sel (nukleus). Pada tahun 1927, Griffith dan Avery mengungkapkan bahwa bakteri memiliki suatu senyawa mengekspresikan sifat-sifat yang berbeda tetapi belum mengetahui dengan jelas penyebabnya. Penelitian lebih lanjut oleh Avery, MacLeod, dan McCarthy pada tahun 1944 menunjukkan bahwa perbedaan ekspresi sifat tersebut karena struktur seperti tangga, terdiri dari dua pita yang berlawanan arah, yang akhirnya dikenal dengan DNA. Penemuan struktur DNA oleh James Watson dan Francis Crick pada tahun 1953 merupakan temuan penting dalam perkembangan genetika di dunia. Model struktur DNA hasil analisis Watson dan Crick mampu menjelaskan bagaimana DNA membawa informasi genetis sebagai cetak biru (blueprint) yang dapat dicopy dan diperbanyak saat sel membelah sehingga sel-sel baru juga mengandung informasi genetis yang sama. Inilah mengapa sifat dan ciri fisik seseorang berasal dari pewarisan orang tua dan nantinya akan diturunkan ke anak cucunya.
Terjadinya pewarisan sifat dari kedua orang tua, ayah dan ibu ke anak turunannya adalah akibat terjadinya peleburan kromosom dari sel sperma dan sel telur. Masing-masing sel kelamin memiliki 22 autosom dan satu gonosom yaitu $\mathrm{X}$ atau $\mathrm{Y}$. Peleburan dua set sel kelamin sekaligus menyatukan kromosom pada sel sperma dan sel telur. Sel telur yang telah dibuahi, bakal calon anak atau zigot, mengandung dua set gen dalam kromosom dengan demikian untuk setiap pasangan kromosom yang bersesuaian, kita mewarisi satu kromosom dari ayah dan satu kromosom dari ibu. Ini menjelaskan mengapa ada sifat dan karakter tubuh kita yang mirip ayah dan di sisi lain ada sifat dan karakter tubuh kita yang mirip ibu (Griffiths dkk., 1996).

Semua kandungan DNA yang ada pada sel dinamakan genom. Genom manusia terdiri dari genom inti sel (nukleus) dan genom mitokondria. Genom mitokondria (ekstranuklear), mengandung lebih banyak kromosom, sehingga jika pada kromosom inti, masing-masing hanya terdiri dari 2 copy, maka kromosom mitokondria tersusun dari ribuan copy. Penyakit yang disebabkan oleh mutasi pada gen di dalam mitokondria biasanya diwariskan dari ibu ke anak karena mitokondria seorang manusia adalah hasil pewarisan dari ibu. Hal ini disebabkan mitokondria lebih banyak ditemukan di dalam sel telur daripada sperma. Setelah fertilisasi mitokondria dari spermatozoa juga akan mati sehingga hanya meninggalkan mitokondria dari sel telur (Griffiths dkk., 1996).

\subsubsection{DNA dalam Barang Bukti Forensik}

Seorang penjahat tanpa disadari pasti akan meninggalkan sesuatu (jejak), sehingga ketika polisi dipanggil ke tempat kejadian serius, tempat kejadian perkara (TKP) segera ditutup dengan pita kuning police line untuk mencegah pencemaran buktibukti penting. Ahli forensik harus bergegas ke tempat kejadian sebelum bukti penting yang mungkin membantu mengungkap kejadian hilang/dirusak. Barang bukti forensik yang ditemukan harus diambil sampelnya untuk diperiksa di laboratorium demi mendapatkan data pelengkap dan pendukung. Salah satu pemeriksaan yang penting dan hasilnya bisa didapat dengan cepat adalah tes sidik DNA. Tes sidik DNA dalam 
kasus forensik utamanya dilakukan untuk tujuan identifikasi korban walaupun sekarang tes sidik DNA juga bisa dilakukan untuk melacak pelaku kejahatan.

Pelacakan identitas forensik akan dilakukan dengan mencocokkan antara DNA korban dengan terduga keluarga korban. Hampir semua sampel biologis tubuh dapat digunakan untuk sampel tes siik DNA, tetapi yang sering digunakan adalah darah, rambut, usapan mulut pada pipi bagian dalam (buccal swab), dan kuku. Untuk kasus-kasus forensik, sperma, daging, tulang, kulit, air liur atau sampel biologis apa saja yang ditemukan di tempat kejadian perkara (TKP) dapat dijadikan sampel tes sidik DNA (Lutfig and Richey, 2000).

\subsubsection{Identifikasi Forensik dengan Tes Sidik DNA}

Pemeriksaan identifikasi forensik merupakan pemeriksaan yang pertama kali dilakukan, terutama pada kasus tindak kejahatan yang korbannya tidak dikenal walaupun identifikasi juga bisa dilakukan pada kasus non kriminal seperti kecelakaan, korban bencana alam dan perang, serta kasus paternitas (menentukan orang tua). Secara biologis, pemeriksaan identifikasi korban bisa dilakukan dengan odontologi (gigigeligi), anthropologi (ciri tubuh), golongan darah serta sidik DNA. Sidik DNA merupakan gambaran pola potongan DNA dari setiap individu. Seperti halnya sidik jari (fingerprint) yang telah lama digunakan oleh detektif dan laboratorium kepolisian sejak tahun 1930 (Kartika dan Evy, 2011).

Pada tahun 1980, Alec Jeffreys dengan teknologi DNA berhasil mendemonstrasikan bahwa DNA memiliki bagian-bagian pengulangan (sekuen) yang bervariasi. Hal ini dinamakan polimorfisme, yang dapat digunakan sebagai sarana identifikasi spesifik (individual) dari seseorang. Perbedaan sidik DNA setiap orang atau individu layaknya sidik jari, sidik DNA ini juga bisa dibaca. Tidak seperti sidik jari pada ujung jari seseorang yang dapat diubah dengan operasi, sidik DNA tidak dapat dirubah oleh siapapun dan dengan alat apapun. Bahkan, sidik DNA mempunyai kesamaan pada setiap sel, jaringan dan organ pada setiap individu. Oleh karena itu sidik DNA menjadi suatu metodeidentifikasi yang sangat akurat.
Hanya sekitar 3 juta basa DNA yang berbeda antara satu orang dengan orang lain. Para ahli menggunakan daerah yang berbeda ini untuk menghasilkan profil DNA dari seseorang individu, menggunakan sampel dari darah, tulang, rambut atau jaringan tubuh yang lain. Pada kasus kriminal, biasanya melibatkan sampel dari barang bukti dan tersangka, mengekstrak DNAnya, dan menganalisanya untuk melihat suatu daerah khusus pada DNA (marker). Para ilmuwan telah menemukan marker di dalam sampel DNA dengan mendesain sepotong kecil DNA (probe) yang masing-masing akan mencari dan berikatan dengan sekuen DNA pasangan/komplementernya pada sampel DNA. Satu seri probe akan berikatan dengan DNA sampel dan menghasilkan pola yang berbeda antara satu individu dengan individu yang lain. Para ahli forensik membandingkan profil DNA ini untuk menentukan apakah sampel dari tersangka cocok dengan sampel pada bukti. Marker sendiri biasanya tidak bersifat khusus untuk setiap individu, jika dua sampel DNA mirip pada empat atau lima daerah, sampel tersebut mungkin berasal dari individu yang sama. jika profil sampel tidak sama, berarti seseorang tersebut bukan pemilik DNA yang ditemukan pada lokasi kriminalitas. Jika pola yang ditemukan sama, tersangka tersebut kemungkinan memiliki DNA pada sampel bukti Marks dkk, (1996).

DNA yang biasa digunakan dalam tes adalah DNA mitokondria dan DNA inti sel. DNA yang paling akurat untuk tes adalah DNA inti sel karena inti sel tidak bisa berubah sedangkan DNA dalam mitokondria dapat berubah karena berasal dari garis keturunan ibu, yang dapat berubah seiring dengan perkawinan keturunannya. Kasus-kasus kriminal, penggunaan kedua tes DNA di atas, bergantung pada barang bukti apa yang ditemukan di Tempat Kejadian Perkara (TKP). Seperti jika ditemukan puntung rokok, maka yang diperiksa adalah DNA inti sel yang terdapat dalam epitel bibir karena ketika rokok dihisap dalam mulut, epitel dalam bibir ada yang tertinggal di puntung rokok. Epitel ini masih menggandung unsur DNA yang dapat dilacak. Misalnya dalam kasus korban ledakan bom, serpihan tubuh para korban yang sulit dikenali 
diambil sekuens genetikanya. Bentuk sidik DNA berupa garis-garis yang mirip seperti bar-code di kemasan makanan atau minuman. Membandingkan kode garis-garis DNA, antara 30 sampai 100 sekuens rantai kode genetika, dengan DNA anggota keluarga terdekatnya, biasanya ayah atau saudara kandungnya, maka identifikasi korban forensik atau kecelakaan yang hancur masih dapat dilacak. Untuk kasus pemerkosaan diperiksa spermanya tetapi yang lebih utama adalah kepala spermatozoanya yang terdapat DNA inti sel di dalamnya. Jika di TKP ditemukan satu helai rambut maka sampel ini dapat diperiksa asal ada akarnya. Namun untuk DNA mitokondria tidak harus ada akar, cukup potongan rambut karena diketahui bahwa pada ujung rambut terdapat DNA mitokondria sedangkan akar rambut terdapat DNA inti sel.

Teknologi DNA memiliki

keunggulan mencolok dalam hal potensi diskriminasinya dan sensitifitasnya maka tes sidik DNA menjadi pilihan dalam penyelidikan kasus-kasus forensik dibanding teknologi konvensional seperti serologi dan elektroforesis. Kedua tes ini hanya mampu menganalisis perbedaan ekspresi protein dan membutuhkan sampel dengan jumlah relatif besar. Tes sidik DNA sebaliknya hanya membutuhkan sampel yang relatif sedikit. Metode Southern Blots misalnya sudah mampu menedeteksi loki polimorfisme dengan materi DNA sekecil 60 nanogram, sedangkan metode Polymerase Chain Reaction (PCR) hanya memerlukan DNA sejumlah beberapa nanogram saja. Pada kasus kriminal dengan jumlah sampel barang bukti yang diambil di TKP sangat kecil dan kemungkinan mengalami degradasi maka metode yang cocok dan sensitif adalah PCR (Marks dkk, 1996).

\subsubsection{Short Tandem Repeat (STR)}

Restriction Fragment Length Polymorphism (RFLP) adalah salah satu aplikasi analisis DNA asli pada penelitian forensik. Dengan perkembangan dan adanya teknik analisis DNA yang lebih baru dan lebih efisien, RFLP tidak lagi digunakan karena membutuhkan sampel DNA yang relatif banyak. Selain itu sampel yang bisanya diperoleh juga biasanya sudah terdegradasi oleh faktor lingkungan, seperti kotoran atau jamur, tidak dapat digunakan untuk RFLP. RFLP merupakan teknik sidik DNA berdasarkan deteksi fragmen DNA dengan panjang yang bervariasi. Awalnya DNA diisolasi dari sampel yang kemudian dipotong dengan enzim khusus restriction endonuclease. Enzim ini memotong DNA pada pola sekuen tertentu yang disebut restriction endonuclease recognition site (sisi yang dikenali oleh enzim restriksi). Ada atau tidaknya sisi yang dikenali ini di dalam sampel DNA menghasilkan fragmen DNA dengan panjang yang bervariasi. Selanjutnya potongan fragmen tersebut akan dipisahkan dengan elektroforesis pada gel agarose $0,5 \%$. Fragmen DNA kemudian dipindahkan dan difiksasi pada pada membran nilon dan dihibridisasi spesifik dengan pelacak (probe) DNA berlabel radioaktif yang akan berikatan dengan sekuen DNA komplementernya pada sampel. Metode ini akhirnya muncullah pitapita yang unik untuk setiap individu (Marks dkk., 1996).

Keberhasilan metode ini sangat tergantung pada isolasi sejumlah DNA tanpa terdegradasi. Pada persidangan kasus kriminal, hal ini bisa menjadi suatu masalah jika jumlah DNA sangat sedikit dan kualitasnya rendah. Ini terlihat dari hasil pitapita sidik DNA yang tidak tajam. Jumlah pita sidik DNA yang dapat dianalisis sangat penting karena jika jumlah pitanya berkurang akibat terdegradasi secara statistik menurunkan taraf kepercayaan. Semakin banyak pita yang cocok akan semakin meyakinkan. Oleh karena itu pada kasus ini dapat digunakan teknik sidik DNA dengan memperkuat (mengamplifikasi) daerah spesifik pada DNA yang disebut mikrosatelit dengan satuan pengulangan yang dinamakan Simple Tandem Repeat (STR). Analisis dengan PCR pada daerah STR tersebut dapat mengatasi masalah tersebut. Teknik ini dapat menghasilkan data dalam waktu singkat dan sangat cocok untuk otomatisasi (Yeni Hartati dan Iman Maksum, 2004).

\section{HASIL PENELITIAN}

Analisis yang dilakukan pada penelitian menggunakan analisi deskriptif dengan melihat tabulasi silang (cross-tab) antara lama 
paparan 7 hari dan 14 hari terhadap kadar dan kemurnian DNA.

\section{1 hubungan antara lama paparan 7 dan 14 hari terhadap kadar DNA}

hubungan antara lama paparan 7 dan 14 hari terhadap kadar DNA berdasarkan uji statistik dapat dilihat pada tabel 1 .

Tabel 1 kadar DNA paparan 7 Hari dan 14 hari

\begin{tabular}{|l|l|l|l|l|}
\hline No & $\begin{array}{l}\text { Kadar } \\
\text { paparan } \\
7 \text { Hari }\end{array}$ & $\begin{array}{l}\% \\
\text { kadar } \\
\text { paparan } \\
7 \text { hari }\end{array}$ & $\begin{array}{l}\text { Kadar } \\
\text { paparan } \\
14 \text { hari }\end{array}$ & $\begin{array}{l}\% \\
\text { kadar } \\
\text { paparan } \\
14 \text { hari }\end{array}$ \\
\hline 1 & 329 & $5 \%$ & 602 & $10 \%$ \\
\hline 2 & 255,5 & $4 \%$ & 339,5 & $5 \%$ \\
\hline 3 & 105 & $2 \%$ & 108,5 & $2 \%$ \\
\hline 4 & 399 & $6 \%$ & 479,5 & $8 \%$ \\
\hline 5 & 549,5 & $9 \%$ & 560 & $9 \%$ \\
\hline 6 & 427 & $7 \%$ & 497 & $8 \%$ \\
\hline 7 & 308 & $5 \%$ & 353 & $6 \%$ \\
\hline 8 & 462 & $7 \%$ & 486 & $8 \%$ \\
\hline total & 2835 & $45 \%$ & 3425,5 & $55 \%$ \\
\hline
\end{tabular}

Tabel 1 menunjukkan bahwa lama paparan 7 hari dan 14 hari kadar DNA semua sampel 1 sampai 8 mengalami kenaikan dari paparan hari ke 7 ke 14 dengan rata - rata kenaikan sebesar $1,375 \%$. Data yang didapat berdistribusi tidak normal, sehingga dilakukan tes non-parametrik yaitu Willcoxon Test. didapatkan hasil $\mathrm{P}=0,012$ dimana $\mathrm{P}$ lebih kecil dari 0,05. Maka, antara lama paparan 7 hari dan 14 hari terdapat perbedaan kadar DNA dalam sampel.

\subsection{Hubungan antara lama paparan 7 dan 14 hari terhadap Kemurnian DNA}

Proses isolasi sampel DNA dari cincin elastomer selesai, kemudian dilanjutkan dengan uji kadar DNA dan kemurnian DNA. dilakukannya uji ini, untuk mengetahui berapa nilai kadar dan kemurnian yang terkandung pada masing-masing sampel dari hari ke-7 dan hari ke-14. Hubungan antara lama paparan 7 dan 14 hari terhadap kemurnian DNA berdasarkan uji statistik dapat dilihat pada Tabel 2 berikut ini.
Tabel 2. Kemurnian DNA paparan 7 hari dan 14 hari

\begin{tabular}{|l|l|l|l|l|}
\hline No & $\begin{array}{l}\text { Kemurnian } \\
\text { DNA } \\
\text { paparan } \\
\text { hari }\end{array}$ & $\begin{array}{l}\text { \% } \\
\text { paparan } \\
\mathbf{7} \text { hari }\end{array}$ & $\begin{array}{l}\text { Kemurnian } \\
\text { DNA } \\
\text { paparan 14 } \\
\text { hari }\end{array}$ & $\begin{array}{l}\text { \% } \\
\text { paparan } \\
\mathbf{1 4} \text { hari }\end{array}$ \\
\hline 1 & 1,362319 & $7 \%$ & 1,829787 & $9 \%$ \\
\hline 2 & 1,351852 & $7 \%$ & 1,672414 & $9 \%$ \\
\hline 3 & 1,764706 & $9 \%$ & 1,9375 & $10 \%$ \\
\hline 4 & 1,325581 & $7 \%$ & 1,427083 & $7 \%$ \\
\hline 5 & 1,602041 & $8 \%$ & 1,649485 & $8 \%$ \\
\hline 6 & 1,326087 & $7 \%$ & 1,753086 & $9 \%$ \\
\hline 7 & 0,114286 & $1 \%$ & 0,155385 & $1 \%$ \\
\hline 8 & 0,157143 & $1 \%$ & 0,185333 & $1 \%$ \\
\hline Total & 9,004014 & $46 \%$ & 10,61007 & $54 \%$ \\
\hline
\end{tabular}

Berdasarkan data diatas (Tabel 2) menunjukkan bahwa lama paparan 7 hari dan 14 hari terhadap kemurnian DNA adalah keseluruhan sampel 1 sampai 8 mengalami kenaikan dengan rata -rata kenaikan sebesar $0,875 \%$. Data yang diperoleh berdistribusi normal secara statistik, sehingga dilakukan tes parametrik menggunakan Uji $\mathrm{T}$ Berpasangan (T-Paired) Test. Dari hasil uji T Berpasangan didapatkan hasil $\mathrm{P}=0,016$ dimana $\mathrm{P}$ lebih kecil dari 0,05. Maka dapat disimpulkan bahwa, antara lama paparan 7 hari dan 14 hari terdapat perbedaan kemurnian DNA dalam sampel.

\subsection{Visualisasi hasil elektroforesis dan pengecatan pada locus D13S317}

Setelah diperoleh hasil uji kemurnian dan kadar DNA, seluruh sampel di elektroforesis sesuai ketentuan lokus dan berdasarkan hari paparan yaitu hari ke-7 dan hari ke-14. Berdasarkan dari visualisasi hasil elektroforesis pada lokus D13S317 dan D18S51 di peroleh data sebagai berikut (Gambar 1 dan 2). 


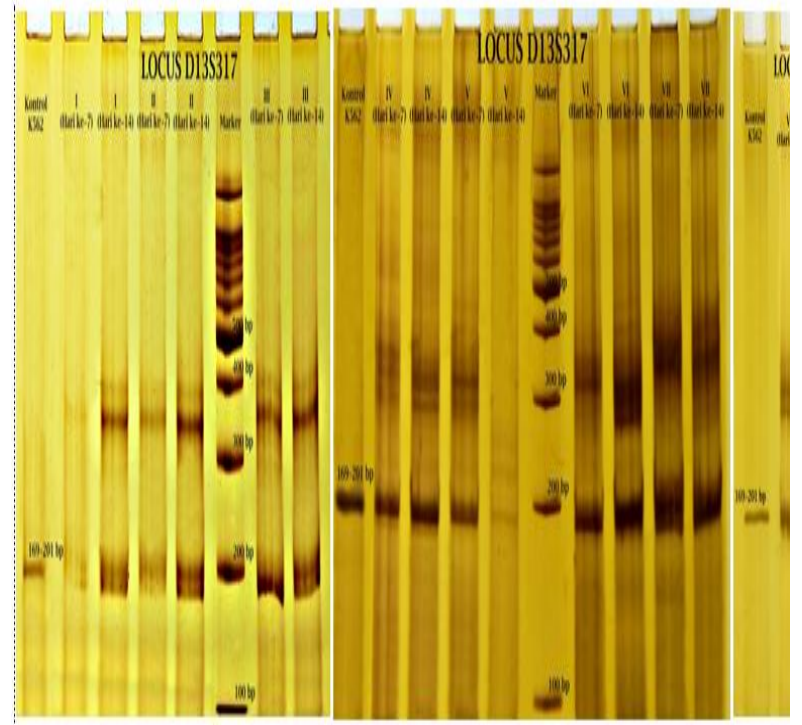

Gambar 1. Visualisasi Hasil Elektroforesis Pada Lokus D13S317 dari cincin elastomer.

Keterangan Gambar 1:

Sampel I hari ke-7 dan hari ke-14: 169-201bp

Sampel II hari ke-7 dan hari ke-14 : 169-201 bp

Sampel III hari ke-7 dan hari ke-14: 169-201 bp

Sampel IV hari ke-7 dan hari ke-14: 169-201 bp

Sampel V hari ke-7 dan hari ke-14: 169-201 bp

Sampel VI hari ke-7 dan hari ke-14: 169-201 bp

Sampel VII hari ke-7 dan hari ke-14: 169-201 bp

Sampel VIII hari ke-7 dan hari ke-14: 169-201 bp

Marker: 100-500 bp

Kontrol K562 : 169-201 bp

Dari visualisasi hasil elektroforesis pada lokus D13S317 (Gambar 1) menyatakan bahwa semua sampel terdeteksi pada kisaran 169-201 bp (pasang basa). Hasil tersebut sesuai dengan kontrol K562 yang menyatakan kisaran pasang basa seluruh sampel pada 169$201 \mathrm{bp}$.

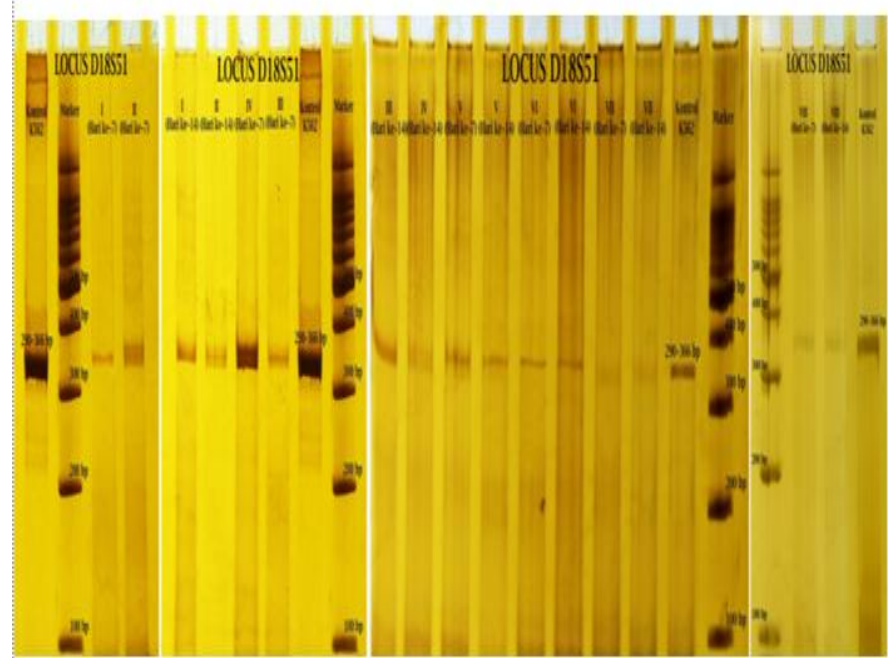

Gambar 2. Visualisasi Hasil Eletroforesis Pada Lokus D18S51 dari cincin elastomer

Keterangan Gambar 2:

Sampel I hari ke-7 dan hari ke-14: 290-366bp

Sampel II hari ke-7 dan hari ke-14 : 290366bp

Sampel III hari ke-7 dan hari ke-14: 290366bp

Sampel IV hari ke-7 dan hari ke-14: 290366bp

Sampel V hari ke-7 dan hari ke-14: 290-366bp Sampel VI hari ke-7 dan hari ke-14: 290366bp

Sampel VII hari ke-7 dan hari ke-14: 290366bp

Sampel VIII hari ke-7 dan hari ke-14: 290366bp

Marker: 100-500 bp

Kontrol K562 : 290-366bp

Dari visualisasi hasil elektroforesis pada lokus D18S51 (Gambar 2) menyatakan bahwa semua sampel terdeteksi pada kisaran 290-366 bp (pasang basa). Hasil tersebut sesuai dengan kontrol K562 yang menyatakan kisaran pasang basa seluruh sampel pada 290366bp.

\section{PEMBAHASAN}

Dari analisa data statistik menggunakan Uji Wilcoxon dan Paired $\mathrm{T}$ Test terdapat perbedaan antara lama paparan 7 hari dan 14 hari terhadap kadar dan kemurnian DNA. Hasil ini didasarkan pada nilai signifikasi atau $\mathrm{P}=0,012$ dan $\mathrm{P}=0,016$ dimana nilai $\mathrm{P}$ lebih kecil dari $\alpha(0,05)$.

Terdapat perbedaan antara lama paparan terhadap kadar dan kemurnian DNA adalah 
sesuai dengan literatur bahwa salah satu faktor yang mempengaruhi kualitas DNA adalah lama paparan disamping juga ada faktor lain yaitu Suhu, Kelembapan, (dapat mempengaruhi pertumbuhan mikroorganisme) paparan zat kimia, sinar UV (lampu, Sinar matahari), dan enzim - enzim yang merusak DNA (DNAse).

Visualisasi hasil PCR melalui elektroforesis dan pengecatan pada locus STR D13S317 dengan rentang panjang lokus antara 169 - 201 bp dan D18S51 dengan rentang panjang locus 290 - 366 bp didapatkan gambaran yang bagus pada pemotretan menggunakan kamera digital pada semua sampel.

\section{KESIMPULAN}

Dari pembahasan diatas, disimpulkan bahwa cincin elastomer ortodontik dapat digunakan dalam proses identifikasi untuk kepentingan forensik.

\section{UCAPAN TERIMAKASIH}

Penelitian ini didukung oleh Indah Nuraini Masjkur dan Ida Kumalasari selaku teknisi di Laboratorium Human Genetic Institute Tropical of Disease University of Airlangga

\section{DAFTAR PUSTAKA}

Baty, D.L Stone, D.j. , von Fraunhofer, J.A. , 1994, Synthetic elastomeric chains: A literature review, Am. J. Orthod Dentofacial Orthop, vol. 105, pp. 536-42. (Baty, Stone, \& Fraunhover, 1994)

Butler, J.M. (2001). STR Analysis for human testing. STR Typing current protocols in Human Genetics Unit.14.8., pp 1-37

Butler, J.M., Yin, S., \& Bruce R.M. (2003). The Development of Reduced Size STR Amplicons as Tools for Analysis of Degraded DNA, National Institute of Standards and Technology.

Fadel, B. , Brinkmann, J. , \& Miethke, R, 1992, Discloration of A-elastics and power chains by different foods and liquids, Am J. Orthod Dentofacial Orthop, vol. 105 no. 6, pp. 615. (Fadel, Brinkman, \& Miethke, 1992)

JBP Vol. 19, No. 1, April 2017 - Januar Alif
Gabriel, M.N., Huffine, E.F., Holland, M.M., Parsons, T.J. (2001) Improved mtDNA sequence analysis of forensic remains using a "mini-primer" set amplification strategy, J Forensic Sci 46:247

Gill, P., Whitaker, J., Flaxman, C. (1992). An Investigation of the rigor of interpretation rules for STRs derived from less than $100 \mathrm{pg}$ of DNA. Forensic Sci. Int. 112:17-40

Genge, N.E ; 2003, The Forensic Casebook. Eburypress. Great Britain, London (Genge, 2003).

Griffiths, Miller, Suzuki, Leontin, Gelbart. 1996. An Introduction To Genetic Analysis. USA: W. H. Freeman and Company. (Griffith, Miller, Suzuki, Leontin, \& Gelbart, 1996)

Holmes, J. , Barker, M.K. , E.K. , \& Tuneay, O.C. , 1993, Cytotoxity of orthodontic elastic. Am J. Orthod. Dentofacial Orthop. , vol. 104 no. 2, pp. 188-19. (Holmes, Barker, E., \& Tuneay, 1993)

Mark, D. B., Marks, A. D., \& Smith, C. M. (1996). Basic Medical Biochemistry. Batimore: Williams \& Wilkins.

Marks, M. H., \& Cam, H. M. (1989). Atlas of Adult Prosthodontic: Functional and Esthetic Enchancement. London: Lea and Febiger.

Pertiwi, K. R., \& Cahyaningrum, P. (2012). Hereditas Manusia Buku Satu. Yogyakarta: FMIPA UNY.

Pertiwi, K. R., \& Yulianti, E. (2011). Pengembangan Modul Pengayaan OSN SMP Materi Forensik. Yogyakarta: FMIPA UNY.

Raharjo, P. (2009). Diagnosis Orthodontik. Airlangga University Press: Surabaya.

Taloumis, L. J., Smith, T. M., Hondrum, S. O., \& Larton, L. (1997). Force Decay and Deformation of the Orthodontic Elastomeric Ligatures. Am. J. Orthod Dentoficial Orthop, vol. 111 no. 1, pp 1-11. 
Jurnal Biosains Pascasarjana Vol. 19 (2017) pp

(C) (2017) Sekolah Pascasarjana Universitas Airlangga, Indonesia

Yudianto, A. (2015). Pemeriksaan Identifikasi

Forensik Molekuler. Global Persada Press.

Surabaya. ISBN 978-602-7676-15-2

JBP Vol. 19, No. 1, April 2017 - Januar Alif 